\title{
Conversational Implicature in Beauty and Beast Movie Directed by Bill Condon
}

\author{
Sayyid Khairunas ${ }^{1}$, Juniato Sidauruk ${ }^{2,}$ Rizky Mirani Desi Pratama ${ }^{3}$, Tesalonika Omega M.D.N ${ }^{4}$ \\ 1,2,3,4 Universitas Bina Sarana Informatika \\ email: ${ }^{1}$ sayyid.skh@ bsi.ac.id, ${ }^{2}$ juniato276@gmail.com, ${ }^{3}$ rizky.rrr@ bsi.ac.id, ${ }^{4}$ thessalonika98@yahoo.co.id

\begin{tabular}{ccc}
\hline Diterima & Direvisi & Disetujui \\
$16-01-2020$ & $19-02-2020$ & $25-02-2020$ \\
\hline
\end{tabular}

\begin{abstract}
The objective of this research is to find out and analyze the types of conversational implicature and the maxim violation in Beauty and the Beast movie. Beauty and the Beast movie was directed by Bill Condon and released in 2017. The method used to conduct this research is descriptive qualitative method. To analyze the types of conversational implicature and the maxim of violation, the writers retrieved the theory from P.H.Grice. There are two types of conversational implicature and there are four maxims in cooperative principles. The result of this research indicates that: (1) There are two types of conversational implicature occured in Beauty and the Beast movie; those are generalized conversational implicature and particularized conversational implicature. The most common types of conversational implicature that occur in Beauty and the Beast movie is generalized conversational implicature, (2) There are four maxim which violated in Beauty and the Beast movie; those are maxim of quality, quantity, relation and manner. The most violated maxim in Beauty and the Beast movie is maxim of quantity.
\end{abstract}

\section{Keyword: Conversational Implicature, Maxim, Movie}

Intisari- Tujuan dari penelitian ini adalah untuk mengetahui dan menganalisis jenis-jenis implikatur percakapan dan pelanggaran maksim dalam film Beauty and the Beast. Film ini disutradarai oleh Bill Condon dan dirilis pada 2017. Metode yang digunakan untuk melakukan penelitian ini adalah metode deskriptif kualitatif. Untuk menganalisis jenis implikatur percakapan dan pelanggaran maxim, penulis mengambil teori dari P.H.Grice. Ada dua jenis implikatur percakapan dan ada empat maxim dalam cooperative principles. Hasil penelitian ini menunjukkan bahwa: (1) Ada dua jenis implikatur percakapan yang terjadi dalam film Beauty and the Beast; mereka adalah implikatur percakapan umum dan implikatur percakapan partikular. Jenis implikatur percakapan yang paling umum yang terjadi dalam film Beauty and the Beast adalah implikatur percakapan umum, (2) Ada empat maxim yang dilanggar dalam film Beauty and the Beast; mereka adalah maxim of quality, quantity, relation and manner. Maxim yang paling banyak dilanggar dalam film Beauty and the Beast adalah maxim of quantity.

Kata Kunci: Implikatur Percakapan, Maxim, Film

\section{INTRODUCTION}

Language is used for communication. Through communication people can get or give some information from others. When people communicate with others, they have to make sure that the message can be delivered and received well. The scientific study of language is called linguistics. Linguistics is divided into two kinds, they are macrolinguistic and microlinguistic. Macrolinguistic is divided into some division; they are Psycholinguistics, Neurolinguistics, and Ethnography. While, microlinguistic is divided into some division, they are Morphology, Phonetics, Phonology, Syntax, Semantics, Sociolinguistics and Pragmatics.

Pragmatics is the study about the speaker meaning. In pragmatics, students learn about how to understand the speaker meaning by the utterance. According to (Fromkin, Rodman, \& Hyams, 2003): "Pragmatic is concerned with the interpretation of linguistic meaning in context". Pragmatics also overwhelms the implicit meaning called implicature.

Implicature usually occurs in speech or conversation. According to (George Yule, 2006; Griffiths, 2006), "Implicature to account for what a speaker can imply, suggest, or mean is distinct from what the speakers literally says". To learn more about implicature the writers takes some definition from the experts. According to Grice, there are two types of Implicature; Conventional Implicature and Conversational Implicature. Conventional implicature are not based on the cooperative principle or the maxim, they don't have to occur in conversation and they don't depend on social context for their 
interpretation (George Yule, 2006). Implicature is divided into two categories; they are Conventional Implicature and Conversational Implicature.

Conversational implicature is implicature which happen with the common words or common knowledge which is non-temporary. Whereas, Conversational Implicature is implicature which occurs in conversation which is temporary.

This research is intended to help the readers to understand more about conversational implicature including the types of conversational implicature. Conversational implicature is divided into two types: Generalized Conversational Implicature and Particularized Conversational Implicature.

In communication the speaker and the listener must follow the rules in conversation called Maxim. Maxim is conversation rules consisting of four kinds, they are maxim of quality, maxim of quantity, maxim of relation, and maxim of manner. When the speaker and the listenener violated maxim, it will result conversational implicature. If someone violated maxim it looks like normal conversation result in people not aware that a maxim violation has occurred.

When communicating sometimes the message to be conveyed is not delivered properly. (Taylor, 1987) proposed four maxims to explain how people cooperate when they speak: Quantity, Quality, Relation, and Manner. When a maxim is violated (or "flouted"), There are four maxim; Maxim of Quality, Maxim of Quantity, Maxim of Relation, and Maxim of Manner.

According to (Griffiths, 2006), conversational implicature is divided into two types; generalized conversational implicature and particularized conversational implicauture.

Based on the explanation above, the writers are interested to analyze about types of conversational implicature and conversational implicature which is caused by maxim violation. The object of this research is Beauty and the Beast movie released in 2017. Rising that introduction, the writers give the title of this research is "Conversational Implicature in Beauty and the Beast Movie directed by Bill Condon".

\section{RESEARCH METHODOLOGY}

Method which is used in this paper is descriptive qualitative method. This method is used to help the writers to analyze the movie. The data are obtained from the conversations that exist in the Beauty and the Beast movie. There are some procedures to analyze the movie. First, the writers need to find a suitable movie to analyze. Second, the writers must watch the movie repearedly, in order to find the appropriate data. Third, the writers look for the theory that the writers will be used for analysis. Fourth, the writers note every conversation that would have conversational implicature, and the last is analyzing the converastion using the theory that the writers has found.

\section{FINDING AND RESULTS}

\section{Types of Conversational Implicature}

To analyze about the type of conversational implicature that exist in Beauty and The Beast movie, the writers must really understand and learn what is meaning of the types of conversational implicature. Conversational implicatures is divided into two types: generalized conversational implicature and particularized conversational implicature.

\section{a. Generalized Conversational Implicature}

Data 1

$\begin{array}{ll}\text { Monsieur Jean } & \text { : "Good morning Belle!" } \\ \text { Belle } & : \text { "Good morning monsieur } \\ & \text { Jean. Have you lost } \\ & \text { something again? }\end{array}$

Monsieur Jean : "Well I believe I have, the problem is I can't remember what. Oh well, I'm sure it will come to me.

This conversation occurs when Belle meets Jean in front of Jean's house, from the questions that given by Belle as if indicating that belle already know the habit of Jean who often lost his goods. To calculate additional meaning "I believe I have, the problem is I can't remember what" that is conveyed by Monsieur Jean it is may imply that actually he did not lost his goods. Belle does not need special knowledge to understand the meaning of the sentence. From the explanation above, it can be concluded that this conversation included in Generalized Conversational Implicature.

\section{Data 2}

Monsieur Jean
Belle




\section{Monsieur Jean : "Sounds Boring"}

The conversation occurs when belle wants to go to the Père Robert's place. Jean conveys additional meaning via implicature "Sounds boring" which imply that Monsieur Jean does not like to read a book about two lovers in Fair Verona. To understand the implicature provided by Jean, Belle does not require any special knowledge to interpret the implicature because Belle has read the book. In this conversation Jean gives the opinion that the book about two lovers in Fair Verona Jean sounds boring it is because maybe Jean does not like the book and therefore he stated that the book is boring, but not for Belle because as known that Belle love reading books. Thus the conversation is classifed into Generalized Conversational Implicature.

Data 3

Robert : "Ah if it isn't, the only bookworm in town. So, where did you run off this week?"

Belle : "Two cities in Northern Italy. I didn't want to come back! Have you got any new places to go?"

Robert : "I'm afraid not. But you may reread any of the old ones that you'd like."

This conversation happened when Belle and Robert were in Robert's place. The implicature occurred when Belle asked about new places Robert would visit, then Robert replied with 'I'm afraid not" which means that he does not yet have a new place to visit. To calculate the additional meaning of the implicature, Belle does not require any special knowledge to understand its implicature. Thus, it is classified into Generalized Conversational Implicature.

\section{Data 4}

Lefou : "So, moving on?"

Gaston : "No, lefou. The ones who play hard to get that are always the sweetest prey. That's what makes Belle so appealing, she hasn't made a fool of herself just to gain my favor. What would you call that?"

Lefou : "Dignity?"

Gaston : "It's outrageously attractive, isn't it?"

In the conversation between Lefou and Gaston, to calculate additional meaning from the sentence "The ones who play hard to get that are always the sweetest prey" Which means that Gaston assume that someday he will get belle and marry her, it can also mean that he will not give up before getting Belle and will do anything to get Belle. To calculate the implicature Lefou does not need a special knowledge to understand it. Thus, it is classified into types of Generalized Conversational Implicature.

Data 5

Gaston : "I heard you had trouble with the Headmaster."

Belle : "He never liked me either."

Gaston : "Can I give you a little advice about the villagers though?"

Belle : "They're never going to trust the kind of change you're trying to bring. All I wanted was to teach a child to read."

Gaston :"The only children you should concern yourself with .. are your own."

Belle : "I'm not ready to have a child"

Gaston : "May be you have not met the right man"

The conversation occurs when Belle and Gaston talk in front of Belle's house. Problems arise when Belle caught teaching reading one of the children in the village when she was washing her clothes. It is in the know by the head master in the village which resulted in belle removed from the washing the clothes. This is also known by the Gaston who immediately approached Belle in front of her house, he implied something through the phrase "The only children you should concern yourself with .. are your own" The sentence can be interpreted as a suggestion but different from the Gaston, Gaston uses that phrase to imply his original purpose to marrying Belle. Belle does not need a special knowledge to understand the implicature conveyed by Gaston. Thus, it is classified into generalized conversational implicature.

Data 6

Belle : "It is a small village Gaston. I've met them all."

Gaston : "Well, maybe you should take another look, some of us have changed,"

Belle : "Gaston, we could never make each other happy. No one can changed that much."

It is known that Gaston is obsessed by Belle and wants to marry her soon. Knowing if Belle is having trouble with Head master in their village, it is used by Gaston to seduce belle. But it does not work because Belle is very dislike Gaston. 
Belle states implicature through the phrase "We could never make each other happy. No one can change that much" which can be interpreted as a rejection that Belle does not like Gaston and will not marry him. To understand the implicature that conveyed by Belle, Gaston does not require any special knowledge to understand it. Thus, this conversation is classified into the generalized conversational implicature.

\section{Data 7}

Gaston : "Oh, Belle do you know what happens to spinster in this village, after their father is die?"

$\begin{array}{cc}\text { Agatha } & \text { :"Coins? Got any spare coins?" } \\ \text { Gaston } & \text { "They beg for scarps. Like poor } \\ \text { Belle } & \text { Agathe. It is our world Belle." } \\ & \text { : "For simple folk like us, it } \\ & \text { doesn't any better. I might be a } \\ & \text { farm girl, but I'm not simple. And } \\ & \text { I'm never going to marry you } \\ \text { gaston, I'm sorry!" }\end{array}$

In the conversation to calculate additional meaning of "For simple folk like us, it doesn't any better" that is conveyed by Belle. It does not need special knowledge to understand the impliature. By talking like that Belle makes it clear that if she married Gaston she would not have any effect on his life, followed by the next sentence that makes it clear that Belle will never marry Gaston. Thus, it is classified into generalized conversational implicature because it does not need a special knowledge to understand the implicature.

\section{Data 8}
Lumiere : "Look Cogsworth! A beautiful girl" Cogsworth : "Yes, I can see it's a girl. I lost my hands not my eyes."

As known in the movie that everyone who was in the palace at the party that night, at the magic and they were transformed into goods that could move and speak. Lumiere and Cogsworth are the example of it. Lumiere is the candlestick that can move and speak like human, and also Cogsworth. Cogsworth is the clock with eyes and mouth so it can see and speak like human. So the conversation between Lumiere and Cogsworth are started when Belle entered the palace to find her father. To calculate additional meaning of "I lost my hands not my eyes" that is conveyed by Cogsworth, it does not need special knowledge to understand it. Because Lumiere already knows that Cogsworth has eyes and he can also see that there is girl entering the palace, and the sentence shows cognitive of Cogsworth to Lumiere who still told him to see a girl entering the palace.

\section{Data 9}

Lumiere : :You must forgive first impression, I hope you are not too startled."

Belle :"Why would I be startled? I'm talking to a candle"

Lumiere : "Candleabra, please. Enormous different, but consider me at your service. The castle is your home now so fell free to go anywhere you like."

Cogsworth : "Except the west wing. Which we do not have"

The conversation happened when belle walked on a bridge in the palace. Lumiere and Cogsworth try to establish a good relationship with Belle so that Belle does not leave the palace. To calculate additional meaning that is conveyed by Lumiere "The castle is your home now, so feel free to go anywhere you like" by speaking like that Lumiere and Cogsworth had a goal to keep Belle from leaving the palace, because Lumiere wondered if Belle was one of the girls who would break the spell. Belle does not need any special knowledge to understand the implicature because Belle may assume that it is just ordinary conversation, Thus, it is classified into generalized conversational implicature.

\section{Data 10}

Gaston

: "Picture it, lefou! A rustic cabin, my latest kill roasting on the fire adorable children running around us as my love rubs my tired feet. But what does belle say? "I will never marry you, Gaston!"

Lefou : "You know, there are other girls."

Gaston : “A great hunter doesn't waste his time on rabbits"

The conversation is between Gaston and Lefou, they are talking about a Belle who does not want to marry Gaston. Lefou offers another woman to be Gaston's wife, but Gaston refuses and will still fight for Belle. This is delivered by Gaston via the phrase "A great hunter does not waste his time on rabbits" which can be interpreted that Gaston will not seek another woman, and he does not want to waste time with other women. To understand these implications, Lefou does not require any special knowledge then the implications are included in the generalized conversational implicature. 


\section{Data 11}

Belle

: "I want to help you; there must be some way to break the curse."

Cogsworth

Mrs.Pots

: "Well, there is one"

: "It's not for you to worry about, lamb. We've made our bed and we must lie in it."

The implicatures occur when Belle wants to help all people in the palace to break the spell. But when Belle asks about what can be done to break the spell, Mrs. Pots says if belle does not have to think about it and immediately divert the conversation with the phrase "We've made our bed and we must lie in it." Through that phrase Mrs.Pots does not want Belle to know about what it can do to break the spell, in order to keep Belle from leaving the palace. With that phrase, Belle understands what Mrs. Pots is trying to convey so Belle does not ask about it anymore.

\section{Data 12}

$\begin{array}{ll}\text { Chip } & \text { : "What is it? What's there?" } \\ \text { Mrs. Pots } & \text { : "I'll tell you when you are } \\ \text { older" } & \text { : "Okay, I'm older." }\end{array}$

The conversation happened when Mrs.pots and Chip walked out of the library in the palace. When Chip asked Mrs.pots something about what happened, her mother refused to answer it by saying "I'll tell you when you are older" Which means Mrs.Pots refuses to answer it because, according to Mrs.Pots chip is not old enough to know about what is going on. To understand the implicature of the sentence the audience does not need to have any special knowledge. It is concluded that this conversation belongs to a generalized conversational implicature.

\section{Data 13}

$\begin{array}{ll}\text { Belle } & \text { : "I never thanked you for saving } \\ \text { my life" } & \text { : "Well, I never thanked you for } \\ \text { not leaving me to be eaten by the } \\ \text { wolves." } \\ \text { : "They know how to have a good } \\ \text { time." } \\ \text { Belle } \\ \text { Beast } \\ \text { Belle } & \begin{array}{l}\text { laughter dies" } \\ \text { : "Me too" }\end{array}\end{array}$

The conversation happened while Belle and Beast talking in the palace's garden. They are remembering when the two are helping each other in the woods. Beast hel ps Belle and his horse as he is interrupted by wolves. Belle also helped the
Beast who run out of power and was slightly hurt by the wolf bites. To calculate additional meaning "They know how to have a good time" that was conveyed by Belle. Beast does not need special knowledge to know that belle is talking about the people in the palace who look very happy and know how to make that time. Thus, it is classified into generalized conversational implicature.

\section{b. Particularized Conversational Implicature}

\section{Data 14}

Belle

: "I don't understand why you're all being so kind to me. Surely, you are as a trapped here as I am. Don't you ever want to escape?"

Mrs. Pots : :The master's not as terrible as he appears. Somewhere deep in his soul, there's a prince of a fellow who just waiting to be set free."

In the conversation Mrs. Pots conveys additional meaning via implicature "The master's not as terrible as he appears". To understand the additional meaning, Belle must know the Beast longer then Belle knows how the original character of the Beast is, and she will find the reason why all the people in the palace did not leave Beast. Then Belle will need a special knowledge to understand it. Thus, it is classified into Particularized Conversational Implicature.

\section{Data 15}

Gaston : "You are the wildest most gorgeous thing I have ever seen. Nobody deserves you. But at least I know our children will be beautiful."

Lefou : "Am I catching you at a bad time?"

Gaston : "What is it, Lefou?"

Lefou : "A certain damsel is in distress"

Gaston : "Ah, it's hero time"

The conversation occurs when belle is expelled from the laundering place. Lefou finds out and immediately reports the incident to Gaston. The conversation occurs when belle is expelled from the laundering place. Lefou finds out and immediately reports the incident to Gaston. The phrase "A certain damsel is in distrees" was used by Lefou to report the incident to Gaston, it implies that there is a girl who needs the help of a Gaston. Gaston is very fond of Belle, then without knowing who is in a certain damsel by Lefou. Gaston immediately helped her, because they had the same knowledge or special knowledge that someone who called certain damsel was Belle. From the explanation it can be concluded that the conversation is included 
in particularized conversational implicature.

\section{Data 16}

Lumiere : "Do not be alarmed, this is just your wardrobe. Meet Madame de Garderobe, a great singer."

Cogsworth : "When she can stay awake,"

Madame : "Cogsworth! A diva needs her beauty rest"

Lumiere : "Stay with us Madame, we have someone for you to dress".

The conversation happens when Belle has arrived in the room that will be her room later. There she met a huge wardrobe named Madame de Gaderobe. Madame de Gaderobe was a great singer at the palace, but because of magic she turned into a huge wardrobe. Through the words spoken by Cogsworth "When she can stay awake", he implies that Madame is very fond of sleeping and if Madame is asleep usually takes a long time. To understand a conversation above Belle requires special knowledge of Madame, so that phrase is included in the particularized conversational implicature.

\section{Maxim Violation}

In this discussion, the writers will discuss about maxim violation that happen in Beauty and The Beast Movie used the theory from Grice about Cooperative Principle's and it's Maxim. As it is known that Grice said there are four maxims; Maxim of Quality, Maxim of Quantity, Maxim of Relation, and Maxim of Manner. For analysis about the four maxims, the writers must really understand about the explanation of four maxims. Thus, the writers will explain the data and the analysis below:

\section{a. Maxim of Quality}

\section{Data 17}

Lumiere : : "You must forgive first impressions, I hope you are not too startled."

Belle : "Why would I be startled? I'm talking to a candle."

Lumiere : "Candlelabra please, Enormous different, but consider me at your service. The castle is your home now, so feel free to go anywhere you like."

Cogsworth : "Except the west wing.... Which we do not have,"

\footnotetext{
Belle : "Why? What's in the west wing?"

Lumiere : "Nothing ...."

Cogsworth : "Nothing"
}

This conversation consist of three people, they are Belle, Lumiere, and Cogsworth. Lumiere and Cogsworth invite Belle to get out from the prison to move to the room which they had prepared, to go to the room they had to pass the bridge which being a link between a palace and the prison. From above the bridge they can see some side of the palace, and then the maxim violation happened. In accordance with the theory that Grice made about maxim of quality which requires the speaker to speak the truth. In the conversation Cogsworth states there is no west wing in the palace trough the sentence "Except the west wing... which we do not have" in fact there is, but west wing is the secret place that cannot be known by strangers. West wing is the secret place in the palace that used by Beast to save the curse rose that were given by the fairy on that night after she condemned the palace and everyone in that palace. Lumiere and Cogsworth are two people who get the curse, they turn into candle and clock who can talk and move. From the explanation above it can be concluded that Cogsworth has violated maxim of quality because he does not tell the truth about the west wing.

\section{Data 18}

\section{Someone in tavern}

Gaston

Maurice

Maurice is the Belle's father, who was trying to find help because her daughter is locked up in the prison in the palace. That night Maurice tried to find help in the village tavern where the villagers used to gather. As known that is a man who loves belle but not vice versa. Gaston is interested to help Maurice because he thinks that through this may be he can get a love from Belle, and the end they go together to help belle. They travel at night, on the way to the palace Lefou, Gaston and Maurice through a forest. In the forest they heard the roar of wolves. Hearing the roar of the wolf, Maurice became more convinced that they were near from the palace, unfortunately Maurice forgot the way to the palace. Evidently Maurice and Gaston argue because Gaston proposes to return to the village, but Maurice still wants to continue the journey to the palace. Eventually Gaston and Lefou left Maurice in the woods, tied to a tree. The next day Maurice was found by Agathe and brought back to the tavern. Gaston was surprised that he saw 
Maurice in the tavern with the other villagers. As he recalled, he is leaving Maurice in a forest tied to a tree and how could he escape from the bond. To keep his good name Gaston answered a question from someone in tavern with a lie through the phrase "I've spent the last five days trying to find you" in fact Gaston is trying to kill Maurice and leave him in the forest with the thought that belle will fall in his arms because she already has no one else in the village to guard her and of course Belle will think about it. However, in the movie Maurice is saved by Agathe, a woman who releases Maurice from the tree ties in the forest as she searches for firewood and brings him back to the village. Based on the explanation Gaston violates the theory of the maxim of quality which requires the speaker to tell the truth.

\section{b. Maxim of Quantity}

\section{Data 19}

\author{
Monsieur Jean : "Where are you off to?" \\ Belle : "To return this book to Pere \\ Robert, it is about two lovers in \\ Fair Verona." \\ Monsieur Jean : "Sounds boring."
}

Belle is a girl who likes to read book, she is often spelled out odd by the villagers because she is different from other women in the village. The piece of the conversation above happened when Belle wanted to return the book to Pere Robert on the way Belle meets Monsieur Jean. Pere Robert is a man who has quite a collection, so Belle often borrows a book of collections from Pere Robert to read. In the conversation Belle was violated maxim of quantity trough the sentence "It is about two lovers in Fair Verona". In accordance with the theory that made by Grice about maxim of quantity; Make your contribution as informative as is required, but in the conversation belle give more information about the book that should not be delivered, because may be the additional information that belle give is not important or not needed.

\section{Data 20}

Lefou : "So moving on?"

Gaston : "No, Lefou! It's the ones who play hard to get that are always the sweetest prey. That what makes Belle so appealing, she hasn't made a fool of herself just to gain my favor. What would you call that?"

This conversation happened when Gaston get the rejection from Belle, as known that Gaston is really in love with Belle and always trying to get her. Gaston is a handsome man in the village, for some reason he is very in love with Belle an ordinary girl who is often spelled out odd by other villagers. Gaston is a little arrogant and someone who does not give up on reality, the fact that Belle does not like him at all. In accordance with the theory that made by Grice about maxim of quantity which states that the speaker and the hearer have to give the contribution as much as required, then from the conversation above Gaston give more contribution because he explained why he does not want to moving on from Belle with sentence "It's the ones who play hard to get that are always the sweetest prey. That is what makes Belle attractive. She hasn't made a fool of herself just to gain my favor." The explanation was made to let Lefou understand that Gaston would not give up to get Belle, but the statement is violates the maxim of quantity because Gaston provides excessive information to Lefou.

\section{c. Maxim of Relation}

\section{Data 21}

Gaston : "Belle, wonderful book you have there."

Belle : "Have you read it?"

Gaston : "Well, not that one. But you know books.... For your dinner table (giving bunch of flower) shall I join you this evening?"

Belle: "Sorry, not this evening,"

This conversation took place in the market when Belle and Gaston met. Gaston is always trying to get close to Belle and trying to seduce her by giving her a bunch flowers and invites her to dinner together. But Belle refuses him because she does not want to give a hope to Gaston who can finally make Gaston think that Belle opens a chance for Gaston to approach her. In maxim of relation the speaker and the hearer were asked to be relevant in communication. The conversation above contains violation maxim of relation through the sentence "Well, not that one. But you know books.... For your dinner table (giving bunch of flower) shall I join you this evening?". it is because Gaston tried to divert the conversation that was initially discussing the book and then suddenly he gave a bunch of flowers and invited Belle to dinner together. The offense was done because Gaston did not want Belle to know that he did not like reading books at all.

\section{Data 22}

Belle : "You know Shakespeare?"
Beast : "I had an expensive education,"
Belle : "Actually, Romeo and Juliet's my

favorite play."


After a few days inside the palace Belle and Beast had started to get used to interacting with each other. Belle has also started to get used to interacting with the items inside the palace, especially Lumiere and Cogsworth who first greeted Belle while she was still in prison. Beast is a prince who is cursed to be a beast because of his attitude, which only judges a person from his appearance. As is known that every prince must have a good education, but it is also owned by Belle although she is not from the royal family. Belle is very fond of reading books, therefore she has extensive knowledge. The statement "I had an expensive education" which delivered by Beast felt less appropriate for the conversation at the time. In accordance with the theory that made by Grice about maxim of relation which requires the speaker and the hearer must be relevant in communicate so the conversation was violated maxim of relation because the conversation is not talking about the education that Belle and Beast have.

\section{d. Maxim of Manner}

\section{Data 24}

Gaston : "Look at her lefou, my future wife. Belle is the most beautiful girl in the village that makes her the best."

Lefou : "She's so well read.., and you are so athletically inclined."

Gaston : "I know"

Lefou is a Gaston's friend, a man who loves Belle very much. The conversation took place on the hill while they are riding their horse. Gaston opened the conversation with a discussion about Belle, Gaston deeply admired Belle because of her beauty and also her ingenuity. The personality of Gaston is very different with the personality of Belle, if belle is really likes to read books but Gaston prefers to exercise, horse riding and so on. Gaston always hope that someday he can get Belle's love. The conversation above is one example of a conversation that violates the maxim of manner. In 1976 Grice stated that in maxim of manner the speaker must avoid obscurity expression. Obscurity expression occurs when Lefou conveys Gaston's personality which very different from Belle's personality, seen through Lefou's slightly hesitant way and pauses in the sentence he wants to convey.

\section{Data 25}

Gaston :"You are the wildest... most georgeous thing I have ever seen. Nobody deserves you. But at least I know our children will be beautiful".

Lefou : "Am I catching you bad time?"
Gaston
Lefou :"What is it, Lefou?"

Belle gets a reprimand from the Head master in the village because she teaches a little girl to read. Head master gave a warning to Belle and the other villagers put out her clothes from the laundry place. The event is known by Lefou, and Lefou immediately report it to Gaston, because he thinks that Gaston can take the advantages of the incident. In accordance with the theory that made by Grice about maxim of manner which requires the speaker to avoid ambiguity. Ambiguity happen when Lefou said "A certain damsel is in distrees" to Gaston.Lefou should be able to convey that Belle is in bad condition, but because Gaston and Lefou have the same knowledge then Gaston can directly to go to the place that means by Lefou.

\section{Finding of the most maxim which violated in the Movie}

After doing the analysis the writers found thirteen conversations which contain maxim violation in Beauty and the Beast movie. As known that there are four maxims that rules the conversation. They are maxim of quality, maxim of quantity, maxim of relation and maxim of manner. Maxim of quality has three data which violated the maxim. Maxim of relation has two data which violated the maxim, and the last is maxim of manner which has three data that violated the maxim. Based on the data, the writers draw conclusion that the most maxims which are violated in Beauty and the beast movie is maxim of quantity.

\section{CONCLUSION}

The purpose of this study is to identify the types of conversational implicature and the maxims which are violated in Beauty and the Beast movie. Conversational implicature is the implicature that occurs because of maxim violation in conversation. According to Grice there are two types of conversational implicature, they are; generalized conversational implicature and particularized conversational implicature. Generalized conversational implicature is the implicature that arise without any particular context and it does not contain special knowledge to calculate additional meaning, while particularized conversational implicature is the implicature that arises in any particular context and it needs special knowledge to calculate additional meaning. 
After analyzing the types of conversational implicature in Beauty and the Beast movie, the writers draw the conclusion that the most common types of conversational implicature arises in the movie is generalized conversational implicature. According to the finding data, there are thirteen data which are classifeid into generalized conversational implicature and for the particularized conversational implicature, there are six data identified in the movie.

Next, the writers analyzed the four maxims that violated in Beauty and the Beast movie. According to Grice there are for maxims that rules the conversation, they are; Maxim of Quality, Maxim of Quantity, Maxim of Relation and Maxim of Manner. In the movie, the writers found out thirteen data that violated the maxim. Three data for maxim of quality, five data for maxim of quantity, two data for maxim of relation and three data for maxim of manner. According to data finding, it is concluded that maxim of quantity is the most violated in Beauty and the Beast movie.

\section{REFERENCES}

Fromkin, V., Rodman, R., \& Hyams, N. (2003). An Introduction to Language sevent edition. Boston: Michael Rosenberg. https://doi.org/10.1002/9781119990413.ch1

George Yule. (2006). The Study of Language (Third Edit). New York: Cambridge University Press.

Griffiths, P. (2006). An Introduction to English Semantics and Pragmatics. (Heinz Giegerich, Ed.) (First Edit). Edinburgh: Edinburgh University Press.

Taylor, J. R. (1987). Lexical semantics. The Cambridge Handbook of Cognitive Linguistics (First Edit). Melbourne: Press Syndicate of the University of Cambridge. https://doi.org/10.1017/9781316339732.017 